\title{
膀胖腫瘍に対するインターフェロン膀脂腔内注入療法の基礎的研究
}

\author{
岡山大学医学部泌尿器科学教室 (主任 : 大森弘之教授)
}

原雅弘

\section{FUNDAMENTAL STUDIES ON INTRAVESICAL INSTILLATION OF INTERFERONS FOR TREATMENT OF BLADDER CANCER}

\author{
Masahiro Hara \\ Department of Urology, Okayama University Medical School
}

(Director: Prof. H. Ohmori)

The cytotoxic effect of interferons on T24 cells, the established cell line from human urinary bladder cancer, the distribution of the drugs in blood, urine and tissues of various organs and histopathological change in the bladder mucosa in dogs following intravesical instillation of the drugs, were studied. These studies were conducted to investigate the possible application of each type of interferons to intravesical treatment of superfitial bladder cancer.

1) The cytotoxicity of Ro22-8181 (recombinant human interferon $\alpha$ ), GKT- $\beta$ (recombinant human interferon $\beta$ ) and KW2202 (recombinant human interferon $\gamma$ ) on T24 cells was examined by colony formation method and growth inhibition assay. Cytocidal effects of interferons were dependent on dose and exposure time, and GKT $-\beta$ is most effective (GKT $-\beta>$ Ro22-8181 $>$ KW2202). Cytostatic effects of GKT- $\beta$ were also dependent on dose and exposure time.

2) The interferon levels in blood, urine and tissues were measured by FL-Sindbis system following bladder instillation of GKT- $\beta$ or KW2202 in beagle dogs with bilateral cutaneous ureterostomy. No interferons were detected in blood and urine. Bladder mucosa and submucosal layer were observed through a microscope 6 and 10 hours after bladder instillation of GKT- $\beta$ or KW2202 in beagle dogs with bilateral cutaneous ureterostomy. Degeneration of bladder mucosa and submucosal layer was scarcely observed.

The above results suggest that GKT $-\beta$ is a suitable drug for intravesical treatment of bladder cancer.

要旨：表在性膀腅腫瘍に対するインターフェロンの膀脂腔内注入療法への導入を目的として, インター フェロンのヒト膀胱癌由来培養細胞株 $\mathrm{T} 24$ に対する細胞障害作用, ならびに犬膀脱内インターフェロン 注入によるインターフェロンの血中, 尿中移行, 臓器内濃度と, 膀胀粘膜に及ぼす病理組織学的影響に ついて検討を行った。

1）T24細胞を用い, 各種インターフェロンの濃度別, 添加時間別効果を colony formation method, および growth inhibition assay で検討した。インターフェロン $\alpha, \beta, \gamma$ 共に濃度依存性, 時間依存性 の殺細胞効果を示した. 尚, 殺細胞効果は $\beta$ が最も強く, $\alpha, \gamma$ の順であった. インターフェロン $\beta$ の 細胞増殖抑制効果もまた, 濃度依存性, 時間依存性に認められた。

2）ビーグル犬を用い, 両側尿管皮膚瘻を造設, 空置した膀腅内にインターフェロン $\beta$ または $\gamma$ を注入 し, 血中, 尿中移行, 臟器内濃度を FL-sindbis 系により測定した結果, インターフェロンの膀胱腔内注 入による血中, 尿中移行は認められなかった。ささらに, 正常膀胀粘膜, 粘膜下層に対する影響を検討し たが, 病理組線学的変化は極めて軽微であった。

以上の結果より,インターフェロン $\beta$ の膀胼内注入療法の臨床への導入が可能であることが示唆され た。 


\section{緒 言}

制癌剂の膀胱腔内注入療法は表在性膀胱腫瘍に対し 効果的な治療法のひとつである. Adriamycin $(\mathrm{ADM})^{1)}$, Mitomycin-C $(\mathrm{MMC})^{2)}$ および4'-epiadriamycin $\left.(E p i-A D M)^{3}\right)$ などの膀朕腔内注入療法は, 有効率が高い半面, 副作用として正常膀脱粘膜が障害 されて膀胼刺激症状を起こすことが比較的多い，そこ で著者は，有効かつ副作用の少ない薬剤として，イン ターフェロン (IFN)を膀胱腔内注入療法へ応用するこ とを企図し，基礎的検討を試みたので若干の文献的考 察を加えて報告する。

\section{材料並びに方法}

I. 人膀胱癌培養細胞株 T24に対するインター フェロンの殺細胞効果および細胞増殖抑制効果

1. 細胞並びに培養方法

使用した T24細胞は，1970年に Bubenik 等)により Sweden で初代培養され，その後 Czechoslovakia で 樹立株化された人膀脱癌培養細胞株である. 岡山大学 泌尿器科には，1979年12月に日本医科大学附属第一病 院泌尿器科, 中神義三助教授の御好意により提供され た。その生物学的ならびに形態学的性状については教 室の吉本 ${ }^{5)}$ が原著として報告しているのでその詳細は 本論文では省略するが，今回の実験時における single cell ratioは $95 \%$ 以上 plating efficiency は90\%以上で あり colony formation methodに適した細胞株であ る. 培養液は, $10 \%$ calf serum（Gibco）添加 Eagle' s MEM (日水製薬株式会社)を用い, $\mathrm{pH}$ は $\mathrm{NaHCO}_{3}$ を加え約7.2となるように調整した。培養はプラスチッ クシャーレ（3003 dish, Falcon Co. USA）を用い開 放系とし， $37^{\circ} \mathrm{C} ， 5 \% \mathrm{CO}_{2}$ 下で静置培養を行った。継代 は $0.2 \%$ trypsin および $0.04 \%$ EDTA の等量混合液に て行った.

\section{2. 実験方法}

人膀胱癌培養細胞株 $\mathrm{T} 24$ に対するインターフェロ ンの殺細胞効果を colony formation method にて検 討した。 dish 内に semiconfluent monolayer に発育し ている T24細胞を前述のごとく剥離分散し, $10^{5}$ 個 $/ \mathrm{ml}$ の細胞浮遊液を $10 \mathrm{ml}$ ずつ Falcon 3003 dish に inoculate し，48時間培養を行った。ついで, $0.2 \%$ trypsin お よび0.04\%EDTAの等量混合液を加光, pipettingを 行い, single cell suspension とした。これを前述の培 養液にて希釈し，生細胞数100個/dish を含む $3 \mathrm{ml}$ の細 胞浮遊液を作成し，Falcon 3002 dishに分注した。 $37^{\circ} \mathrm{C}, 5 \% \mathrm{CO}_{2}$ 下で 24 時間培養の後, 培養液を除去し,
各種インターフェロンを含む培養液で24時間，あるい は48時間, 同様に incubate しインターフェロンに接触 させた。 その後, 再びインターフェロンを含む培養液 を除去し, Hanks 液にて 2 回洗浄し, 新鮮な培養液を $3 \mathrm{ml}$ 加えた。計12日間 incubate 後にメチルアルコール にて固定し，ギムザ液にて染色後, 細胞数 20 個以上よ りなるコロニ一数を計算した。 実験は各薬剤, 各濃度 あたり 3 枚のシャーレを用い平均值を求めた。 また， この実験は 3 回繰り返し行った。インターフェロンは 蒸留水で溶解後, 培養液で $500,2000,8000 \mathrm{U} / \mathrm{ml}$ の濃 度に稀釈し使用した。インターフェロンは, recombinant human interferon $\alpha$ である Ro22-8181（日本 ロッシュ株式会社, 東京), recombinant human interferon $\beta$ である GKT- $\beta$ (協和発酵工業株式会社, 東京), recombinant human interferon $\gamma$ である KW2202(協和発酵工業株式会社, 東京)を用いた。尚, インターフェロンの調製は添加直前に行った。培養液 のみの場合の colony 数を solvent control とし,さら にインターフェロンを添加した場合の colony 数を求 め, relative plating efficiency 各濃度別に計算し, グラフより LD50 ( $\mathrm{U} / \mathrm{ml})$ を求めた。

さらに人膀胱癌培養細胞株 T24に対するインター フェロンの細胞増殖抑制効果は growth inhibition assay にて検討した. 前述のごとく $\mathrm{T} 24$ 細胞を剝離分 散し, $10^{5}$ 個 $/ \mathrm{ml}$ の細胞浮遊液を $10 \mathrm{ml}$ ずつ Falcon 3003 dish inoculate し，48時間培養を行った.ついで, $0.2 \%$ trypsin怙よび0.04\%EDTAの等量混合液を加え, pipetting を行い, single cell suspension とした。これ を前述の培養液にて稀釈し, 生細胞数 $10^{4}$ 個 $/ \mathrm{ml}$ の細胞 浮遊液を作成し, Falcon 3047 dish に0.5ml 分注した。 $37^{\circ} \mathrm{C}, 5 \% \mathrm{CO}_{2}$ 下で 24 時間培養の後, 培養液を除去し, 各濃度のインターフェロンを含む培養液で 4 日連続 (インターフェロン添加培養液は 24 時間毎に交換)同様 に incubate しインターフェロンに接触させた。 その 後, 再びインターフェロンを含む培養液を除去し, Hanks 液にて 2 回洗浄し, 新鮮な培養液を $0.5 \mathrm{ml}$ 加え た.インターフェロンは, colony formation method で最も強い殺細胞効果を示した GKT- $\beta$ を用い, 蒸留 水で溶解後, 培養液で $10^{2}, 10^{3}, 10^{4} \mathrm{U} / \mathrm{ml}$ の濃度に希釈 乙使用した。培養 $1 ， 2 ， 4 ， 6 ， 8 ， 10 ， 12$ 日目に, 0.2 trypsin および $0.04 \%$ EDTA の等量混合液を加え, pipetting を行い single cell suspension とし, 細胞数 をCoulter 社製の coulter counterにて計測した。

さらに, 前述のごとく生細胞数 $10^{4}$ 個 $/ \mathrm{ml}$ の細胞浮遊 
液を作成し, Falcon 3047 dish に0.5ml 分注した。 $37^{\circ} \mathrm{C}, 5 \% \mathrm{CO}_{2}$ 下で 24 時間培養の後, 培養液を除去し, $10^{3} \mathrm{U} / \mathrm{ml}$ の濃度のインターフェロン $\beta$ を含む培養液 で 2 日，4日， 6 日，あるいは 8 日連続(インターフェ ロン添加培養液は24時間毎に交換) incubate しイン ターフェロン $\beta$ に接触させた。 その後, 再びインター フェロン $\beta$ を含む培養液を除去し, Hanks 液にて 2 回 洗浄し，新鮮な培養液を $0.5 \mathrm{ml}$ 加えた。 incubation は 計 12 日間行い，培養 $1 ， 2 ， 4 ， 6 ， 8 ， 10 ， 12$ 日目 に0.2\%trypsin 拈よび $0.04 \%$ EDTAの等量混合液を 加え, pipettingを行い single cell suspension とし, 細胞数を coultar counter にて計算した。実験に際し ては各濃度あたり 3 枚のシャーレを用い, 平均値を求 めた。

II. ビーグル犬を用いたインターフェロン膀胱腔内 注入後の血中, 尿中移行, 臓器内濃度, および正常膀 胱粘膜に与える影響

1. 材料

生後 $7 \sim 9$ 力月, 体重 $8 \sim 12 \mathrm{~kg}$ の雌性ビーグル犬 （富士アニマルファームより購入）を用いた。

\section{2. 実験方法}

ケタラール $(10 \sim 13 \mathrm{mg} / \mathrm{kg})$ 筋肉内麻酔，およびネ ンブタール（10 15mg/kg）静脈内麻酔下に仰臥位に 固定した後, 経腹膜的に両側尿管を露出, カテーテル （アトム栄養チューブ 4 号)を插入し尿管皮虐瘦を作成 した。ついで，膀胱および尿道を露出し尿道に切開を 加觉, 空置した膀胱腔内にカテーテル（アトム栄養 チューブ 6 号）を挿入し，インターフェロンを注入し 膀胱䅡部を結禁した、インターフェロンは，GKT- $\beta$ (recombinant human interferon $\beta$ ), および control として KW2202 (recombinant human interferon $\gamma$ ) を用い, 膀胱壁の病理組織学的検索および血中, 尿中, 各種臓器への移行の検討には合計 9 頭のビーグル犬を 使用し， 5 群にわけて検討した（Table 1). 第 1 群, 2 群と 5 群は GKT- $\beta 1 \times 10^{8} \mathrm{U}$ を蒸留水 $10 \mathrm{ml}$ に溶解, 第 3 群と 4 群は KW2202 $1 \times 10^{8} \mathrm{U}$ を蒸留水 $10 \mathrm{ml}$ に溶 解した。第 1 群， 3 群は， 6 時間把持，第 2 群，第 4 群は，10時間把持，第 5 群は，2 時間把持とした。血 中濃度については, 注入前, 注入後 2 時間ごとに採血 乙血清を分離し, $-70^{\circ} \mathrm{C}$ に凍結保存の後測定に供し た，尿中濃度については注入前，注入後 2 時間ごとの 尿を採取し，同様に $-70^{\circ} \mathrm{C} に て$ 凍結保存の後，測定に 供した。臓器内濃度は, 膀胱 (三角部, 側壁の粘膜打 よび筇層）腎，肝，心について測定した。第 1 群， 3
Table 1 Experimental method using dogs

\begin{tabular}{|c|c|c|c|}
\hline Group & Drug & $\begin{array}{l}\text { Retained } \\
\text { Time (hrs.) }\end{array}$ & $\begin{array}{l}\text { No. of } \\
\text { Dogs }\end{array}$ \\
\hline 1 & $\begin{array}{l}\mathrm{GKT}-\beta \\
10^{7} \mathrm{U} / \mathrm{ml}\end{array}$ & 6 & 2 \\
\hline 2 & $\begin{array}{l}\mathrm{GKT}-\beta \\
10^{7} \mathrm{U} / \mathrm{ml}\end{array}$ & 10 & 2 \\
\hline 3 & $\begin{array}{c}\mathrm{KW} 2202 \\
10^{7} \mathrm{U} / \mathrm{ml}\end{array}$ & 6 & 2 \\
\hline 4 & $\begin{array}{l}\mathrm{KW} 2202 \\
10^{7} \mathrm{U} / \mathrm{ml}\end{array}$ & 10 & 2 \\
\hline 5 & $\begin{array}{l}\mathrm{GKT}-\beta \\
10^{7} \mathrm{U} / \mathrm{ml}\end{array}$ & 2 & 1 \\
\hline
\end{tabular}

GKT- $\beta$ : Human recombinant interferon $\beta$

KW2202 : Human recombinant interferon $\gamma$

群は 6 時間，第 2 群， 4 群は10時間，第 5 群は 2 時間 把持後屠殺し, 速やかに臓器摘出し, 生塩水にて洗浄 し, $-70^{\circ} \mathrm{C}$ にて凍結保存の後測定に供した. 尚, 測定は 協和発酵工業株式会社, 医薬研究開発部に委託し, FLsindbis 系による抗ウイルス活性を測定した。

正常膀胖粘膜に対するインターフェロンの影響につ いては, 第 1 群， 3 群は， 6 時間, 第 2 群，4 群は, 10時間把持後屠殺し，速やかに膀胱を摘出し光顕的に 検討した。

\section{結 果}

I 。人膀脱癌培養細胞株 T24k対するインター フェロンの効果

1. 人膀胱癌培養細胞株 $\mathrm{T} 24$ に対するインターフェ ロンの殺細胞効果

Fig. 1 に interferon $\alpha, \beta, \gamma$ の24時間接触後, Fig. 2 に48時間接触後の relative plating efficiency を示し た.インターフェロン $\alpha, \beta, \gamma$ 共に濃度依存性の殺細 胞効果を示し,かつその効果は時間依存性でもあった。 尚, 殺細胞効果は $\beta$ が最も強く, 一方 $\alpha, \gamma$ の殺細胞 効果は軽度であった，T24細胞に対するインターフェ ロンの LD50はグラフよりインターフェロン $\alpha, \gamma$ は 24 時間，48時間接触ともに $8000 \mathrm{U} / \mathrm{ml}$ 以上，インター フェロン $\beta$ は24時間接触では $5900 \mathrm{U} / \mathrm{ml} ， 48$ 時間接触 では $480 \mathrm{U} / \mathrm{ml}$ であった（Table 2).

\section{2. 細胞増殖抑制効果}

T24に対する殺細胞効果が最も強力であったイン ターフェロン $\beta$ を用いた。 Fig. 3 に各濃度別の, Fig. 4 に各接触時間別の growth inhibition curve を示し た。濃度依存性および時間依存性細胞増殖抑制効果が 認められた。しかし，インターフェロン $\beta$ 除去後, $10^{2}$ $\mathrm{U} / \mathrm{ml}$ では, 1 日目より, $10^{3} \mathrm{U} / \mathrm{ml}$ では 2 日目より, $10^{4}$ 
Fig. 1 Effects of Various Interferons on the Plating Efficiency of T24 Cells

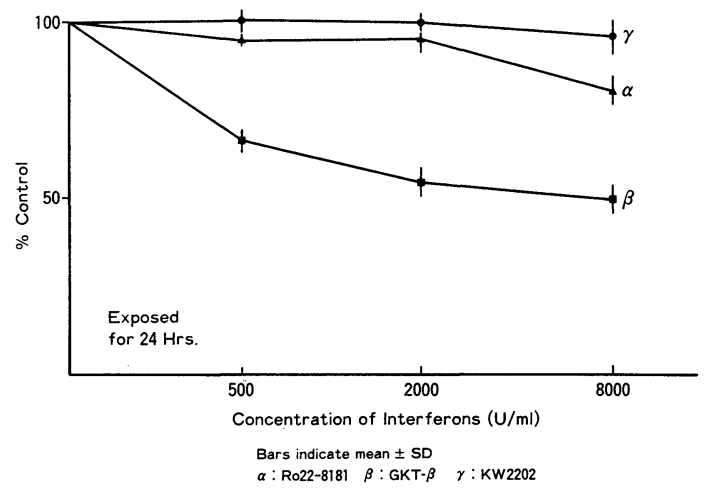

Fig. 2 Effects of Various Interferons on the Plating Efficiency of T24 Cells

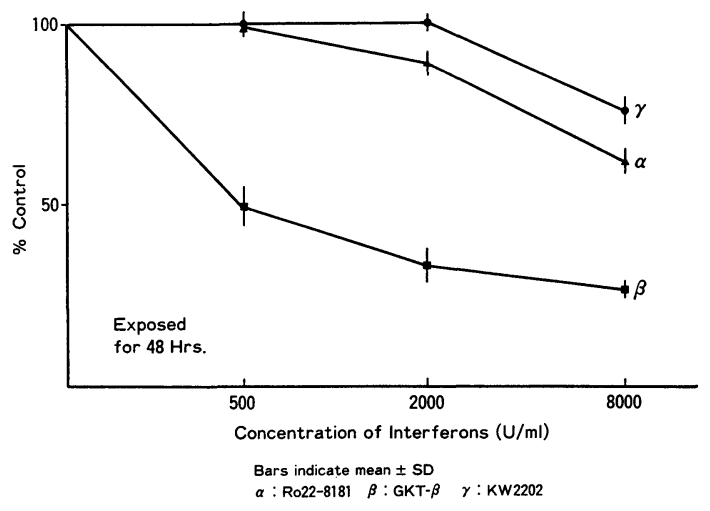

Table $2 \mathrm{LD} 50(\mathrm{U} / \mathrm{ml})$ of various interferons on T24 cells

\begin{tabular}{l|c|r}
\hline \multirow{2}{*}{ Interferon } & \multicolumn{2}{|c}{ Exposed Time (hrs.) } \\
\cline { 2 - 3 } & 24 & \multicolumn{1}{c}{48} \\
\hline Ro22-8181 & $>8000$ & $>8000$ \\
GKT- $\beta$ & 5900 & 480 \\
KW2202 & $>8000$ & $>8000$ \\
\hline
\end{tabular}

$\mathrm{U} / \mathrm{ml}$ では, 3 日目より regrowth が認められ, その後 の増殖は control と同様の傾向を示した.

II. ビーグル犬を用いたインターフェロンの膀胱腔 内注入後の血中, 尿中移行, 臓器内濃度, および正常 膀胼粘膜に与える影響

1. 血中濃度および尿中濃度

血中濃度はGKT- $\beta$ (recombinant human interferon $\beta$ ), KW2202 (recombinant human interferon $\gamma$ ) ともに膀胱腔内注入後, 各時間いずれも
Fig. 3 Effects of GKT- $\beta$ on the Proliferation of T24 Cells

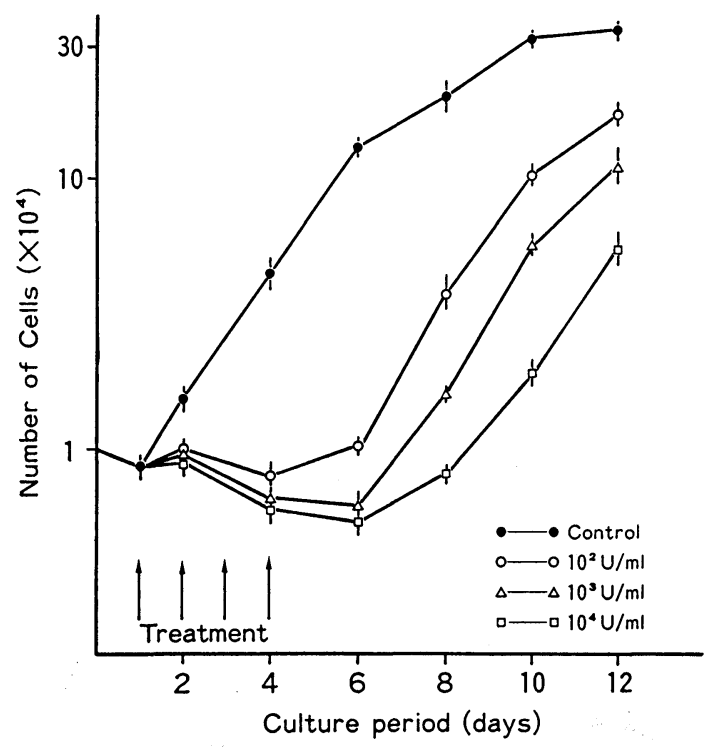

Fig. 4 Effects of GKT- $\beta(1000 \mathrm{U} / \mathrm{ml})$ on the Proliferation of T24 Cells

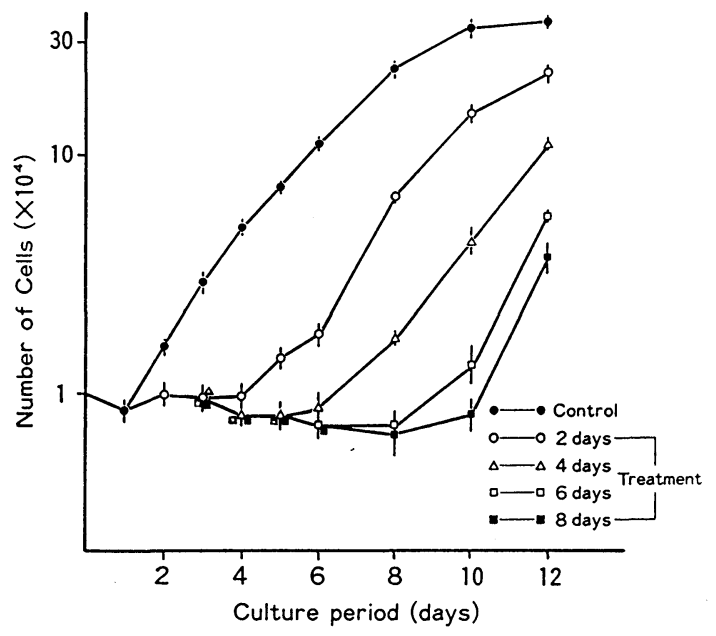

測定限界以下であった（Table 3）。 をた，尿中濃度も 同様に GKT- $\beta$, KW2202 ともに, 各時間いずれも測定 限界以下であった（Table 4).

\section{2. 組織内濃度}

膀胱以外の臓器内濃度は, GKT- $\beta$ 膀胱腔内注入 2 時間後に腎皮質に126U/g.t.w. および髄質に138U/g.t. w. と微量検出された以外はいずれも測定限界以下で あった。膀胱壁の組織内濃度は三角部, および側壁の 粘膜, 筋層について検討したが, GKT- $\beta$ 膀注後 2 時間 
Table 3 Plasma levels of GKT $-\beta$ and KW2202 in dogs

\begin{tabular}{c|c|c}
\hline & GKT $-\beta(\mathrm{U} / \mathrm{ml})^{*}$ & KW2202 $(\mathrm{U} / \mathrm{ml})^{*}$ \\
\hline Before & $<6$ & $<6$ \\
2 hrs. & $<6$ & $<6$ \\
4 & $<6$ & $<6$ \\
6 & $<6$ & $<6$ \\
8 & $<6$ & $<6$ \\
10 & $<6$ & $<6$ \\
\hline
\end{tabular}

* Antivirus activity by $\mathrm{FL}$-sindbis system
Table 4 Urinary levels of GKT- $\beta$ and KW2202 in dogs

\begin{tabular}{l|c|c}
\hline & GKT $-\beta(\mathrm{U} / \mathrm{ml})^{*}$ & KW2202 $(\mathrm{U} / \mathrm{ml})^{*}$ \\
\hline Before & $<6$ & $<6$ \\
$0-2$ hrs. & $<6$ & $<6$ \\
$2-4$ & $<6$ & $<6$ \\
$4-6$ & $<6$ & $<6$ \\
$6-8$ & $<6$ & $<6$ \\
$8-10$ & $<6$ & $<6$
\end{tabular}

* Antivirus activity by $\mathrm{FL}$-sindbis system

Fig. 5 Light microscopic view of the bladder treated with GKT- $\beta$ and KW2202

GKT- $\beta$

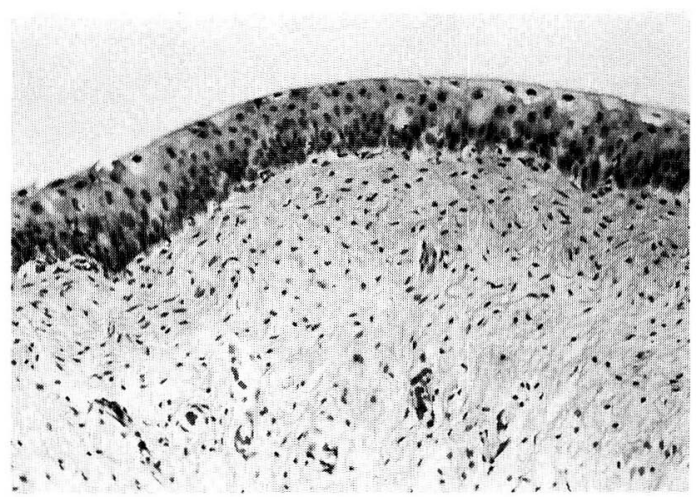

Table 5 Tissue levels of GKT- $\beta$ and KW2202 in dogs killed after 6 and 10 hours retention of interferons $\left(10^{8} \mathrm{U}\right)$

\begin{tabular}{cr|r|r|r|r|r}
\hline \multirow{2}{*}{} & \multicolumn{3}{|c|}{$\begin{array}{c}\text { GKT- } \beta \\
\text { (U/g.t.w.) }\end{array}$} & \multicolumn{2}{c}{$\begin{array}{c}\text { KW2202 } \\
\text { (U/g.t.w.) }\end{array}$} \\
\cline { 4 - 7 } & & 2 hrs. & 6 hrs. & 10 hrs. & 6 hrs. & 10 hrs. \\
\hline Bladder & & & & & & \\
trigone & mucosa & 5850 & 24500 & 2870 & 29800 & 870 \\
& muscle & 4300 & 14320 & 7970 & 25900 & 1310 \\
lateral & mucosa & 4770 & 3650 & 3070 & 6030 & 1240 \\
& muscle & 3200 & 4600 & 2220 & 6110 & 1380 \\
Kidney & coltex & 126 & $<60$ & $<60$ & $<60$ & $<60$ \\
& medulla & 132 & $<60$ & $<60$ & $<60$ & $<60$ \\
Liver & & $<60$ & $<60$ & $<60$ & $<60$ & $<60$ \\
Heart & & $<60$ & $<60$ & $<60$ & $<60$ & $<60$ \\
\hline
\end{tabular}

* Antivirus activity by $\mathrm{FL}$-sindbis system

では膀胼三角部粘膜が最も高く, GKT- $\beta$ 膀注後 6 時 間では, 三角部粘膜, 筋層の濃度はさらに上昇したが, 側壁の濃度は同様であった，GKT- $\beta$ 膀注後10時間で は 6 時間に比して三角部粘膜，筋層の濃度は，著明に 低下した。KW 2202 膀注後 6 時間では, 膀胼三角部粘
KW2202

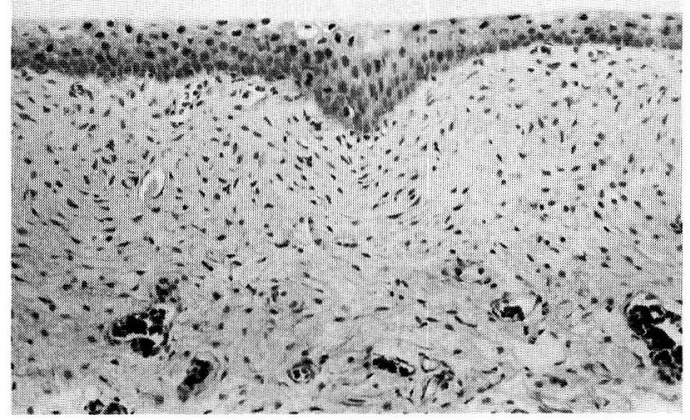

Table 6 Histological findings of bladder wall after intravesical instillation of various interferons

\begin{tabular}{l|c|c|c|c}
\hline \multirow{2}{*}{} & \multicolumn{2}{|c|}{ GKT- $\beta$} & \multicolumn{2}{c}{ KW2202 } \\
\cline { 2 - 5 } & 6 hrs. & $10 \mathrm{hrs}$. & $6 \mathrm{hrs}$. & $10 \mathrm{hrs}$. \\
\hline Mucosa & & & & \\
Exfoliation & - & $-\sim \pm$ & - & - \\
Necrosis & - & - & - & - \\
Submucosa & & & & \\
Edema & - & $-\sim \pm$ & - & - \\
Inflammation & - & - & - & - \\
Necrosis & - & - & - & - \\
\hline
\end{tabular}

- : no change, \pm : slight change

膜, 筋層の順に濃度が高く, KW2202膀注後10時間で は，膀脱組織内濃度は著明に低下した（Table 5)。

3. 膀胼粘膜に対する影響

膀胱粘膜に対する GKT- $\beta$ および KW 2202 の影響を 病理組織学的に検討したが, 粘膜上皮の剝離, 壊死, 粘膜下の浮腫，好中球の浸潤，壊死等の炎症所見はほ とんど認められなかった (Table 6)（Fig. 5).このこ とよりインターフェロンの正常膀胱粘膜への刺激性は 
極めて軽度であることが示唆された。

\section{考 察}

膀胼腫瘍は, 表在性腫瘍と進行癌にわけられ, 表在 性膀胼腫瘍に対してはTUR を主体とした治療が施行 されその予後は良好である。しかし，多中心性に発生 する性質をもち再発を繰り返す傾向が強く，またその 都度 TUR を施行することにより萎縮膀胱となり, 膀 脱全摘除術を余儀なくされることもある。萎縮膀羘を 防ぐために, 我々は再発性の多発性表在性膀胱腫瘍に 対し抗癌剂の膀胼腔内注入療法677) 施行, 腫瘍数ある いは腫場の占拠面積を減少させた後に TURを行って きた。しかし完全寛解例が少ないこと，および副作用 として膀胼刺激症状が認められることが問題となって いる。膀脱腔内注入療法は, 1948年 Semple ${ }^{8)}$ が podophyllinを用いたのが最初であり，1961年 Jones and Swinney ${ }^{9)}$, 1962年 Vennema ${ }^{10)}$ にり thio-TEPA が, low stageの膀胱腫瘍に適応とされた。その後, Ethoglucid $^{11)}, \mathrm{MMC}^{2)}, \mathrm{ADM}^{11}$, Carboquone $(\mathrm{CQ})^{12)}$, Acracinomycin $(\mathrm{ACR})^{13)}$, Bleomycin $(\mathrm{BLM})^{14)}$, $\mathrm{CDDP}^{15) 16)}, \mathrm{BCG}^{17)}, \mathrm{Epi}-\mathrm{ADM}^{3116)}$ な゙かが検討されてい る. 膀胱腔内注入療法のための条件として, 尾崎は ${ }^{199}$, 1）移行上皮癌に感受性があること，2）短時間の接触 で殺細胞効果を有すること，3）血中への移行が低率で あること,4）正常膀胱粘膜への刺激性が少ないことを 挙げている，現在では上記の条件の 1)〜3)を充たす 薬剂として, ADM, MMC が膀胱腔内注入療法に用い られ，比較的良好な治療成績が報告されているが，正 常膀脱粘膜への刺激性が問題となっている。近年にな り BCG の膀脂腔内注入療法が，表在性膀胼腫瘍に対 し有効であるとの報告もされているが20221)，やはり膀 胱刺激症などの副作用が強い様である。

一方，インターフェロン(IFN)は, 1954年, Nagano and $\mathrm{Kojima}^{22}$ とよってウイルス抑制因子として発見 され，1957年に Isaacs and Lindenmann ${ }^{23)}$ にってウ イルスの干渉現象を引き起こすものとして，インター フェロン(interferon) と命名された. その後, インター フェロンは抗ウイルス作用の他に，抗腫瘍作用を含め て種特異性の多面的生物活性物質として認識されるよ らになった。最近になり，細胞から産生される天然の インターフェロン（natural interferon）の他，遺伝子 工学の手法を用いた人工の遺伝子組替えインターフェ ロン（recombinant interferon）が生産可能となり，精 製法も確立され，高純度の IFN 製剂が大量に生産され るようになってきている。
インターフェロンの臨床的治療効果には, 1970年前 半のStrander ら ${ }^{24)}$ の骨肉腫に対する有効性の報告以 来, インターフェロンの細胞増殖抑制作用は, 癌治療 薬として臨床応用がされてきている。インターフェロ ンの全身投与による各種覀性腫場に対する有効性につ いては, 多くの報告がなされている25) 299が，脳腫 瘍 ${ }^{30131)}$, 皮膚悪性腫瘍 ${ }^{32)}$ に対してはインターフェロン の局所投与の方が有効性が高いといら報告も認められ る.

著者は，表在性膀胱腫瘍に対して，尾崎の条件を充 たす抗腫瘍剂を検討していたが，インターフェロンに その可能性を考慮し、インターフェロンの膀胱腔内注 入療法への応用のため基礎的検討を試みた。

インターフェロンの抗腫場作用には直接作用 ${ }^{33) ~ 35)}$

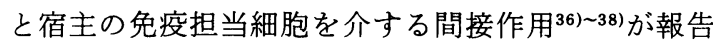
されている．膀胱腔内注入療法は局所投与であるため in vitroでインターフェロンの直接作用について検討 した．直接作用として，インターフェロンは抗細胞作 用があることは知られているが，その作用は静細胞 的 ${ }^{39}$ に作用する場合と殺細胞的 ${ }^{40}$ に作用する場合があ ることが報告されている，著者は，七卜膀胜癌培養細 胞株 $\mathrm{T} 24$ を用い，各種インターフェロンの殺細胞効果 については colony formation methodにて検討した。 インターフェロンはその抗原型の違いにより interferon $\alpha$, interferon $\beta$, interferon $\gamma$ 3 種類に大 別されているため, recombinant type の interferon $\alpha$ (Ro22-8181) interferon $\beta$ (GKT- $\beta$ ), interferon $\gamma$ （KW2202）を本実験に使用した。T24細胞は今回の実 験時において single cell ratio は95\%以上，また plating efficiencyは $90 \%$ 以上であり colony formation methodに適した細胞株である. colony formation method は薬剂に接触した後に真に増殖能力を有する 腫瘍細胞数を，ほぼ正確に把握することができる方法 としてすぐれた薬剤感受性試験 ${ }^{41)}$ とされてい。，著者 の実験では 24 時間インターフェロンを接触させた時の LD50值は, Ro22-8181, KW2202は, 8000U/ml 以上で あったが，GKT- $\beta$ は， $5900 \mathrm{U} / \mathrm{ml} ４$ 48時間接触させた 時の LD50値は, Ro22-8181, KW2202は8000U/ml 以

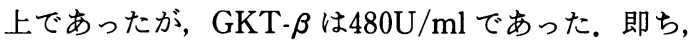
T24細胞は Ro22-8181，KW2202に対し低感受性を示 したが, GKT- $\beta$ は T24細胞に対し濃度依存性, 時間依 存性の最も強い殺細胞効果を持つことが示された，

そこで，T24に対する殺細胞効果が最も強力であっ た GKT- $\beta$ を用い，細胞増殖抑制効果を Growth inhi- 
bition assay で検討したが，T24細胞に対し濃度依存 性括よび時間依存性の強い細胞増殖抑制効果が認めら れた. 即ち, GKT- $\beta$ は T 24 に対し殺細胞的及び静細胞 的に抗腫瘍効果を発揮することが認められた。

インターフェロンの抗腫瘍活性は, 濃度依存性より も時間依存性であるといら報告が多いが，我々の実験 結果でもその傾向が認められる様である，この理由を 考えるに，インターフェロンの生物学的活性は細胞膜 のレセプターと結合し細胞内に侵入した後に発揮され るといわれ42)，インターフェロンに対する腫瘍細胞の 感受性は腫瘍細胞のレセプターの数とその親和性によ るともいわれている43). しかし，各腫瘍細胞のレセプ タ一数は限られているために, 濃度依存性効果には限 界があると推察される。このことについては，各種イ ンターフェロンに対する腫瘍細胞の recepter assay を行い検討する予定である。

インターフェロンは時間依存性の抗腫瑒効果を示す が, 半減期が短く, 数時間で活性の低下をきたすため, 臨床的に膀胼腔内注入療法を行う際には，腫瘍細胞へ の接触時間を長くするために投与回数を増やす必要性 があると思われ，これに依って有効性を高めることが 可能と考える.

次に，膀胱腔内注入療法に抢ける安全性および副作 用について，尾崎の方法 ${ }^{19)}$ を参考に検討を行った。ビー グル犬を用い，両側尿管皮膚瘦を造設し，空置した膀 胱腔内にインターフェロンを注入し，血中; 尿中移行, 臓器濃度, および膀胱粘膜に与える影響について検討 した.

膀胱粘膜からの薬剂の吸収については, 動物実験あ るいは臨床的に種々の薬剤で検討されている，膀胱粘 膜からの吸収は，薬剂の脂溶性あるいは分子量に左右 され(4)，都田ら ${ }^{45)}$ は, FT207と5-FU を膀胼腔内に注入 し吸収効率を検討したところ，FT207は5-FU の23倍 であり,これは薬剤の脂溶性の差によると述べており， 中川ら ${ }^{46}$ は, さらに検討したところ, $\mathrm{pH} 6 \sim 7$ における 非イオン型存在率，即ちイオン化定数の差によるもの と述べている．薬剤の分子量に関してはYeates ${ }^{47}$ は 200 以下の物質は経膀胼的に吸収されるとしている.イ ンターフェロンは分子量約 20000 と非常に大きく経膀 胼的に吸収されにくいものと考学られるが，著者のイ ンターフェロンの膀胖腔内注入に際しての実験でも, 血中尿中にインターフェロンは検出されず，全身的な 副作用は極めて少ないものと考兄られた。

膀腅腔内に注入した薬剤の膀胱粘膜および粘膜下組
織に及ぼす影響については, 各種抗癌剂, $\mathrm{ADM}, \mathrm{CQ}^{48)}$, $\mathrm{CDDP}^{49)}, \mathrm{MMC}^{50)}$, Epi-ADM 等にて, 動物実験ある いは臨床的に検討が行なわれている，教室の津島は， ビーグル犬を用いた ADM，Epi-ADM ${ }^{18)}$ の膀胱腔内注 入実験で，高濃度では粘膜の剝離，粘膜下浮腫等の強 い変化が認められたと報告している，著者はインター フェロンの膀胱腔内注入による膀胼正常粘膜, 粘膜下 組織の変化についてビーグル犬を用いて病理組織学的 に検討したが，粘膜上皮の剥離，粘膜下浮腫，好中球 の浸潤等の炎症所見等は, 汪とんど認められなかった。 このことはインターフェロンが標的細胞としない正常 膀胱上皮細胞には，生物学的活性（抗細胞効果）を発 揮しないことによると考えられた。

以上の実験結果より, GKT- $\beta$ は膀胱癌培養細胞株 T24に対し強い殺細胞効果拈よび細胞増殖抑制効果を 示しまた高濃度の GKT- $\beta$ の膀脂腔内注入による GKT- $\beta$ の血中ならびに尿中への移行は汪とんど無 く, かつ高濃度, 長時間でも膀胱粘膜への刺激性は極 めて少ないことが示唆された。これにより GKT- $\beta$ は 膀脱腔内注入療法として高濃度, 長時間投与が可能で あり，臨床的にもその有効性は高いことが予想され， 臨床的研究を行いたいと考光ている.

\section{結語}

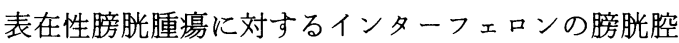
内注入療法への導入を目的としての基礎的研究を行っ た。

1）ヒト膀胱癌由来培養細胞株 T24を用い, 各種イ ソターフェロンの濃度別, 添加時間別効果を colony formation method で検討した. Ro22-8181 (recombinant human interferon $\beta$ ), GKT- $\beta$ (recombinant human interferon $\beta$ ), KW2202 (recombinant human interferon $\gamma$ ) 共に濃度依存性の殺細胞効果を示し， か つその効果は時間依存性でもあった。殺細胞効果は GKT- $\beta$ が最も強く, 一方 Ro22-8181, KW2202の殺細 胞効果は軽度であった。

2）人膀脱癌培養細胞株 T24に対する殺細胞効果が 最も強力であった GKT- $\beta$ を用い, 細胞増殖抑制効果 を, growth inhibition assay で検討した. GKT- $\beta$ は T24細胞に対し強い細胞增殖抑制効果が，濃度依存性 および時間依存性に認められた。

3）ビーグル犬を用い, 両側尿管皮膚瘻を造設し空置 した膀胼内に GKT- $\beta, \mathrm{KW} 2202$ を注入し，血中，尿中 移行, 臓器内濃度を FL-sindbis 系により測定した結 果，インターフェロンの膀胱腔内注入による血中，尿 
中移行は認められず。臓器内移行は膀胼壁には認めら れたが，他臟器には汪とんど認められなかった。さら に正常膀脱粘膜, 筋層に対する影響を検討したが, 病 理組織学的変化は注とんぞ認められなかった。

GKT $-\beta$ は人膀胱癌培養細胞株 T 24 に対し殺細胞効 果拉よび細胞増殖抑制効果があり, 膀胼腔内注入によ る GKT- $\beta$ の血中並びに尿中への移行は認められず, また膀胼粘膜刺激性は, 極めて少ないことが示され, GKT- $\beta$ の膀胼腔内注入療法の臨床への導入が可能で あることが示唆された。

本稿を終えるにあたり, 御指導, 御校閲を賜った恩師大森 弘之教授に深く感謝致します。さらに, 貴重な御助言を賜っ た松村陽右助教授, 直接本実験を御指導下さいました吉本 純講師に深謝致します。 また, 本学癌源研究施設病理学部 門，佐藤二郎教授に感謝致します。最後に，T24細胞を御提 供くださいました日本医科大学付属第一病院泌尿器科, 中 神義三助教授ならびに実験助手をつとめられた守谷由美 子，小坂 民，原淵尚子女史に謝意を表します。

本論文の要旨は, 第76回日本泌尿器科学会総会 (新潟), および第46回日本癌学会総会（東京）にて報告した。

\section{文献}

1）尾崎雄治郎：膀脂腫瘍に対する Adriamycin の膀 脂腔内注入療法。その 1 . 主として臨床成績の検 討。日泌尿会誌，68，934-944，1977.

2）志田圭三，他：膀胼腫瘍に対するマイトマイシン C の膀羘腔内注入療法 (第 1 報). 新薬治験, 21 , 1057-1058, 1967.

3）津島知靖：表在性膀胱腫瘍に対する 4'epiadrimycin の膀胱腔内注入療法 (Randomizedy). 泌尿紀要，31，2215-2218，1985.

4) Bubenik, J., et al.: Established cell line of uriary bladder carcinoma (T24) containing tumor-specific antigen. Int. J. Cancer, 11, 765-773, 1973.

5）吉本 純: 人膀羘癌培養細胞株の性ホルモン感受 性に関する研究. 日泌尿会誌, 72, 192-199, 1981.

6）大森弘之：表在性膀胖腫瑒に対する膀胖腔内注入 療法. 癌と化学療法, 11, 1557-1562, 1984.

7) Matumura, Y., Ozaki, Y., Ohmori, H. and Okayama Urological Cancer Collaborative Group (OUCCG): Intravesical adriamycin chemotherapy in bladder cancer. Cancer Chemo. Pharm., 11(Suppl.), S69-S73, 1983.

8) Semple, J.E.: Papilloma of bladder treated with podophyllin. Preliminary report. Brit. Med. J., 1, 1235-1237, 1948.

9) Jones, H.C. and Swinney, J.: Thiotepa in the treatment of tumors of the bladder. Lancet, 2, 615-618, 1961.
10) Vennema, R.J., et al.: Bladder carcinoma treated by direct instillation of thio-TEPA. J. Urol., 88, 60-63, 1962.

11) Abbassian, A. and Wallace, D.M.: Intracavitary chemotherapy of diffuse non-infiltrating papillary carcinoma of the bladder. J. Urol., 96, 461-465, 1966.

12）土田正義, 熊谷郁太郎：膀腅腫瘍に対する Carboquone の膀脱内注入療法. 泌尿紀要, 22, 263-272, 1976.

13）高井修道，他：Aclacinomycin 膀胱内注入による 膀脂腫瘍の治療. 新薬と臨床, 29, 21-25, 1980.

14）窪田吉信, 他: 膀胱癌の Hyperthermia 療法: Bleomycin 㧍よび放射線との併用について。癌 治療会誌，13，394-405，1978.

15）平尾佳彦, 他：膀脂腫瘍に対する cis-diamminedichloroplatinum (II) の膀胱内注入に関する基礎的 研究. 泌尿紀要, 31，1565-1573， 1985.

16）田中正利, 他：表在性膀朕腫場に対する Cisplatin の膀胱内注入療法. 西日泌尿, 48, 117-121, 1986.

17) Morales, A., Edinger, D. and Brice, A.W.: Intracavitary bacillus Calmette-Guerin in the treatment superficial bladder tumor. J. Urol., 116, 180-183, 1976.

18）津島知靖：膀脂腫县に対する 4'-epiadrimycin の 膀羘腔内注入療法に関する基礎的研究. 泌尿紀要, 31，1945-1956, 1985.

19）尾崎雄治郎：膀脱腫瘍に対する Adriamycin の膀 胱腔内注入療法, その2. 実験的研究. 日泌尿会誌, 69, 817-827, 1978 .

20) Morales, A., Ottenhof, P. and Emerson, L. : Treatment of residual, non-infiltrating bladder cancer with bacillus Calmette-Guerin. J. Urol., 125, 649-651, 1981.

21) de Kernion, J.B., Huang, M., Lindner, A., Smith, R.B. and Kaufman, J.J. : The management of sufperficial bladder tumors and carcinoma in situ with intravesical bacillus Calmette-Guerin. J. Urol., 133, 598-601, 1985.

22) Nagano, Y. and Kojima, Y.: Immunite et interference dans la vaccine. Inhibition de infection determique par le virus inactive. C. R. So. Biol., 148, 750-752, 1954.

23) Isaacs, A. and Lidenmann, J.: Virus interference: I. The interferon. Proc. Roy. Soc. B., 147, 258-267, 1957.

24) Strander, H., Cantel, K. and Caristrom, G.: Clinical and laboratory investigations on man, sys temic administration of potent interferon to man. J. Natl. Cancer Inst., 51, 733-742, 1973.

25) Gutterman, J.U., et al.: Leukocyte interferon induced tumor regression inhumanmetastatic 
breast cancer, multiple myeloma, and malig. nant lymphoma. Ann. Int. Med., 93, 399-406, 1980.

26) Mellstedt, H., et al.: Interferon therapy in myelomatosis. Lancet 1, 245-247, 1979.

27) Kimura, K.: Overview of phase study of human lymphoblastoid interferon (HLBI) for solid tumor and blood cancer in Japan. In: Interferons (ed. Kishida, T.), p. 157-162, 1983.

28）新島端夫：組替方型ヒト白血球インターフェロン $\mathrm{A}(\mathrm{rIFN} \alpha \mathrm{A})$ の泌尿性器系悪性腫場に対する臨床 効果の検討. 癌と化学療法, 12, 921-927, 1985.

29）丸茂 健，他：准行腎細胞癌に対するヒ卜 $\alpha$ 型イ ンターフェロンの抗腫場効果とその免疫学的検 討。日泌尿会誌，76，965-973，1985.

30）永井政勝：悪性脳腫瘍に対する human fibroblast interferon の臨床的検討. 日癌誌会誌, 18, 60-68, 1983.

31）高倉公朋：インターフェロン- $\beta$ （MR-21）の悪性 脳腫瘍に対する臨床効果の検討。日癌治会誌, 22, 801-808, 1987.

32) 石原和之: Human fibroblastoid interferon (HuIFN $\beta$ ) による皮席悪性腫瘍に対する臨床的研 究一局所投与を中心とした検討一. 日癌治療会誌, 18, 41-53, 1983.

33) Gresser, I., Bandu, M.T., et al.: Interferon and cell division VII. Inhibitory effect of highly purified interferon preparations on the multiplication of leukemia L1210 cells. Proc. Soc. Exp. Biol. Med., 142, 7-10, 1973.

34) Yamada, H. and Shmoyama, M.: Growth inhibitory activity of human lymphoblastoid and fibroblast interferons in vitro. Gann, 74, 1983.

35）下山正徳，他：インターフェロンの直接作用的抗 腫瘍活性之臨床治験。癌の臨床，29，589-597， 1983.

36) Gidlund, M., Orn, A., et al. : Enhanced NK cell activity in mice injected with interferon and interferon inducers. Nature, 237, 759-761, 1978.

37) Herbermann, R.R., Ortaldo, J.R. and Bonnard,
G.D. : Augmentation by interferon of human natural and antibody-dependent cell-mediated cytotoxicity. Nature, 277, 221-223, 1979.

38) Scultz, R.M., Papamatheakis, J.D. and Chirigos, M.A.: Interferon, an inducer of macrophage activation by polyanions. Sience, 197, 674-676, 1977.

39) Gresser, I., Tovey, M.G. : Antitumor effects of interferon. Biochim. Biophys. Acta, 561, 231-247, 1978.

40）山田 尚, 下山正徳：ヒト線維芽細胞由来イン ターフェロンの各種造血器腫場由来培養株細胞に 対する增殖抑制作用に対する解析. 癌の臨床, 28 , 1688-1694, 1982.

41）関口 浩：培養ヒト膀脂癌細胞株による制癌剤感 受性試験。日泌尿会誌，74，25-31，1983.

42）米原 伸：インターフェロンのレセプターシステ ム. 癌と化学療法, $11,44-52,1984$.

43）原口惣一,他：組替えインターフェロン $\alpha-2 b$ によ る in vitro 抗腫瘍活性の多面的検討. 癌と化学療 法, 9, 3236-3243， 1986.

44）三品輝男：膀脂腔内注入療法の基礎と臨床。日泌 尿会誌，73，1516-1522，1982.

45）都田慶一, 三品輝男：FT-207 と 5FU の経膀胱吸 収に関する比較。泌尿紀要，28，949-952，1982.

46）中川修一, 他：FT-207 と 5-FU の経膀胼的吸収に 関する比較。泌尿紀要，31，1227-1231，1985。

47）Yeates, W.K.：文献9）ょり引用.

48）岡島英五郎，伊集院真澄，他：膀胱腫場に対する Calboquone の膀腅腔内注入療法に関する基礎的 研究一正常 Beagle 犬に対する Calboquone の膀 胼腔内注入による影響について一。泌尿紀要, 29, 1061-1074，1983.

49）平尾佳彦，他：膀胱腫煌に対する cis-Diamminedichloroplatinum (に)の膀腅腔内注入療法に関寸 る基礎的研究. 泌尿紀要，31，31-38，1985.

50）小川秀爾, 平岡保紀, 河合 博：膀胼腫瘍に対する 抗腫場の膀脂腔内注入療法. 第5報. Mitomycin C の正常膀胼々膀脂腫瘍とに対する作用の相違（基 礎的臨床的研究)。日泌尿会誌, 74, 596-607, 1983 ,

（1988年11月 8 日受理，特別掲載） 